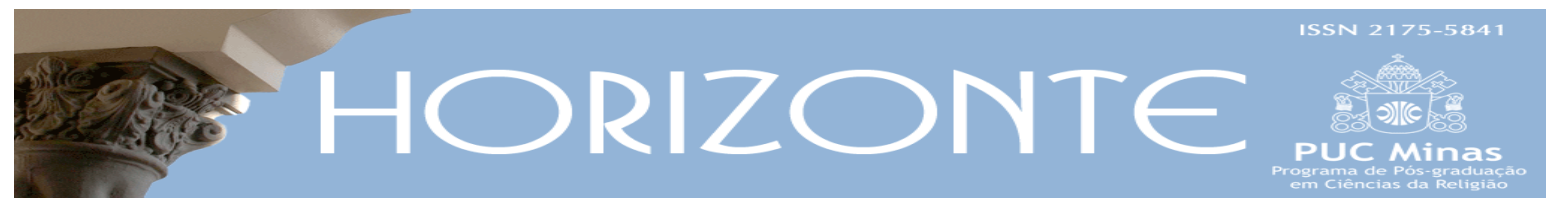

Paper-Comunication

DOI - 10.5752/P.2175-5841.2015v13n37p550

\title{
Spirituality: daring new horizons
}

Espiritualidad: aventurándonos hacia nuevos horizontes

Espiritualidade: ousar novos horizontes

Diarmuid O'Murchu *

The religion of the future will be a cosmic religion. It should transcend personal God and avoid dogma and theology. Covering both the natural and the spiritual, it should be based on a religious sense arising from the experience of all things natural and spiritual as a meaningful unity.

(Albert Einstein,1954).

The 1960s marked a quantum leap in our understanding of Spirituality. Prior to that time, Christians focused on the spiritual life, which meant how best to live out our religious faith in daily existence. However, this more devoted attention to spiritual matters belonged to an elite class of clergy and those in the vowed life. Only a mere handful of lay people managed to attain a degree of spiritual accomplishment. In addition, within the ranks of those with a special vocation, the priest was special; only the priest could serve as a spiritual director, the one considered best acquainted with the care of souls.

Paper-Comunication received on October 07, 2014 and approved on March 18, 2015.

* Member of the Sacred Heart Missionary Order, and a graduate of Trinity College, Dublin Ireland, is a social psychologist most of whose working life has been in social ministry, predominantly in London, UK. Country of origin: Ireland. E-mail: Diarmuid.13@gmail.com 
In this earlier understanding, the following are among the notable features:

1. The Spiritual Life belonged uniquely to Christians. Devotees of other religions were deemed to be outside the Church and therefore beyond salvation. Only Christians were capable of a spiritual life.

2. The primary goal of the spiritual life was salvation of one's individual soul, beyond this vale of tears in the Heaven beyond this earth.

3. Transcending earthly preoccupations (temptations) was the primary means to attain spiritual growth; this was to be done through prayer and penance, and was normally considered either impossible or inappropriate for lay people.

4. The spiritual life entailed special devotion to God through prayer and penance. In this context, prayer usually meant recitation of fixed formulas, e.g., the divine office, the Rosary, along with some well-structured formats for silent prayer. Penance entailed fasting, various forms of bodily deprivation, occasionally flagellation.

5. People were expected to take responsibility for their own spiritual development by following the Church's guidelines on prayer and fasting. Consultation with a priest frequently happened through the confessional.

6. Eucharist did not feature strongly in living out of the spiritual life. For much of Christendom, the celebration of Eucharist was understood as a clericalized priority, related more to the sanctity of the priest himself rather than to the spiritual life more widely understood.

7. Progress in spiritual growth tended to be judged by endurance in pain and suffering. Suffering for its own sake was deemed to be central to spiritual advancement. The Cross as well as the crucified Jesus formed the biblical basis for a "theology" of the spiritual life. 
This approach to the spiritual life is embedded in a quality of consciousness that is difficult to critique because it has enjoyed such unquestioned hegemony over several millennia. Chris Clarke (2005, p. 234) describes this contextual background as “... the shadow side of the triumphant rationality of the West, a rationality which has cut itself off from mystical knowing, and repressed it along with the economic repression of the poor." This essay will explore what is entailed in the contemporary reawakening of the mystical.

\section{The Counter-culture of the 1960s}

Philip Sheldrake (1991) provides a more detailed analysis of how the spiritual life was understood throughout the 2000 years of Christendom. He notes that in the early decades of the $20^{\text {th }}$ century, spirituality began to evolve as a distinctive field of study with the launching of publications like Revue d'Ascetique et de Mystique in 1920 and the Dictionnaire de Spiritualite in 1932. Despite such developments, for much of the $20^{\text {th }}$ century spirituality still referred to the spiritual life as described above. With the counter-cultural upsurge of the 1960s, the term took on new meaning, one that has morphed into several articulations since that time. The following are some of the relevant features characterizing the spiritual awakening of the 1960s:

- A sense of rebellion against all forms of institutionalization (antiestablishment).

- $\quad$ A denunciation of formal religion as staid, rigid and over legalistic.

- $\quad$ Spontaneous expression of religious sentiment (e.g., speaking in tongues).

- Religious ritualization of significant life-experiences - outside and sometimes over against the formal (sacramental) practice of church and religion.

- A widespread curiosity about, and interest in, Eastern forms of meditation.

- A desire to explore mystical/esoteric wisdom through dance, psychedelic drugs, ecstatic states, oriental practices (such as Yoga), martial arts. 
- Various movements to reclaim the sacredness of nature itself, and live in convivial rapport with the natural world.

- As young people began to travel internationally, many sampled the rituals and experiences of other world religions.

- Valuing experience over the dictates of formal religious teaching.

- A strange mixture of individualism and communal experiment.

- God as Holy Spirit gaining a new ascendency (as in Charismatic Renewal and the Pentecostal movement).

For more on the above named features - and others - one can check a range of scholarly analyses. I recommend Robert S. Ellwood (1994), along with Wade Clark Roof $(1993 ;$ 1999). Formal religions continue to be suspicious and dismissive of recent developments in the expansive understanding of Spirituality, and tend to be particularly critical of the distinction between religion and spirituality. For mainline religionists there is only one true faith, that is, the particular religion itself.

Harvey Cox's 1965 bestseller, The Secular City, prophesied that the rise of urbanism and the collapse of traditional religion would pave the way for a brave new secular age. That prediction has not been fulfilled. The new atheists - Richard Dawkins and the late Christopher Hitchens - have captivated a lot of media publicity, but not near as much attention among rank-and-file people. Instead, there has been something of a spiritual renaissance ever since the 1960s, but so eclectic, diffuse and complex, it is difficult to delineate its ingredients and discern its significance for our time. 
Let us review some of the key developments:

1. Spirituality has become a subject in its own right, requiring a quality of research based on a multi-disciplinary analysis. Spirituality has broken away from religion and outstrips it on several fronts (cf. HEELAS; WOODHEAD 2005). Religion tends to be defined in terms of creed, ritual and moral code. Spirituality heavily emphasizes a more authentic quality of relating among diverse peoples, cultures and aspects of the created universe. Spirituality shuns formal doctrines, seeks to keep ritual fluid, flexible and responsive to immediate needs, and adopts moral guidelines along the lines of ethical situations. Formal religions tend to be based on patriarchal and hierarchical structures; spirituality adopts relational networking, within which individual autonomy is strongly cherished.

2. Spirituality expands the notion of the sacred far beyond formal religion. It abhors the dualistic splitting between the sacred v. the secular, earth v. heaven, body v. soul, and matter v. spirit. Spirituality is committed to celebrating commonalities rather than upholding differences. It promotes bridge building seeking to transcend all binary distinctions, an aspiration captivated in words of to the Dalai Lama (posted on Facebook, Sept. 10, 2012): "All the world's major religions, with their emphasis on love, compassion, tolerance, and forgiveness can and do promote inner values. However, the reality of the world today is that grounding ethics in religion is no longer adequate. That is why I am convinced that the time has come to find a way of thinking about spirituality and ethics eyond religion altogether."

3. Spirituality marks a distinctive shift on authoritative truth. It exhibits a strong dislike for magisterial omniscience, and challenges the monopoly of truth adopted by patriarchal cultures, which favor rational discourse, formalized doctrines, rituals and devotions, perceived to be best mediated through a hierarchical structure, with male wisdom and insight to the fore. For the new spirituality, truth belongs more to what in former times was called the "sensus fidelium" (sense of the faithful) arising from shared wisdom - across all religious 
traditions (and beyond) - evolving through dialogue and mutual exploration, adopting structures that are highly fluid and flexible. Authority here is best understood as the facility to discern deeply, and its truthfulness is judged by the ability to generate empowering outcomes - for person and planet alike. Revealed truth is perceived to belong first and foremost to the web of life, and not to formal religion. It is in this organizational realm that spirituality differs so radically from formal religion; it is not at all clear how the new spirituality can hope to impact upon human culture in a more structured and enduring way.

4. In the emerging spirituality, the ecological dimension is a central feature and often exhibiting strong ethical values (while individual morality might be underrated). Care for the environment, strong awareness of environmental threat (on several fronts), and collaboration through networking to address urgent issues, belong integrally to the emerging spirituality. The ecological awareness leads some to embrace larger cosmological and scientific horizons as articulated through the seminal work of the late Thomas Berry, and the insights of quantum physics. These insights are often combined in the commitment to Creation Spirituality, for which Matthew Fox's Original Blessing (1983) is often regarded as a seminal text. With some many environmental threats facing humanity today, contemporary spirituality offers a naming and awareness far more exemplar and empowering than formal religions.

5. Embodiment is another key factor, with obvious challenges for an incarnational faith like Christianity. Embracing the whole person (and not just the soul) is a primary target of contemporary spirituality. How to nourish and love the body appropriately is a complex challenge with several problematic issues particularly around human intimacy and psychosexual expression. The embodied dignity of all other organic creatures is also affirmed. Eco-feminism seeks to reintegrate the abused female body with that of the often abused earth. This focus on the more intimate aspects of human well-being is viewed with great suspicion by 
many major religions, including Christianity despite its claim to be an incarnational faith.

6. Representatives of the formal religions frequently denounce the emerging spirituality as solipsistic and excessively individualistic. The new emergence is often portrayed as a free-for-all, with little regard for convention, tradition, or community. The inherent individualism may need more discerning attention, as it may be arising from earlier times when individual creativity and expression was frequently suppressed - and even repressed - in a culture grossly preoccupied with patriarchal control and domination (see the valuable insights of Douglas Watt in CLARKE, 2005, p. 70-89). On closer examination, the new spirituality strongly endorses communal allegiance but without the organizational strings and controls that typify formal religions.

7. In 2005, British scholars, Jeremy Carrettte and Richard King co-authored the book, Selling Spirituality, critiquing the widespread abuse of spirituality to bolster and advance commercial interests, through popular "new age" branding (also, HEELAS, 2008). This is a timely reminder of how easily people are taken in by gurus, teachers, and entrepreneurs who make big profits on the gullibility of naïve spiritual seekers. While this deviation certainly needs to be confronted, it should not distract from the positive potential and evolutionary significance of the emerging spirituality. Moreover, the solution offered by Carrette \& King - namely, return to formal religion - is definitely not the way to resolve the dilemma.

\section{Features of the Emerging Spirituality}

If this emerging spirituality is an evolutionary development of our age, with a rightness for this time, how do we discern its complex unfolding, naming deviations that may be dangerous and destructive, and, more importantly, identifying positive features that will enhance our lives culturally and spiritually? Chris Saade, social activist, and co-director of the Olive Branch Centre in Charlotte, North Carolina (USA) identifies six central features of the emergent spiritual 
consciousness of the $21^{\text {st }}$. century: Authenticity, Freedom of the Heart, Unification of Paradoxes, Inclusion, Global Solidarity, Love as the Pursuit of Justice (SAADE, 2014, p. 79-115). I will briefly describe each feature:

Authenticity. Life in our postmodern world is often experienced as fragmented, superficial, false, and violent. Many people feel a sense of alienation and anomie and no longer look to formal religion for a meaningful sense of resolution. What does it mean to be real in a world where it is difficult to establish a broad consensus of the reality within which we live, move, and have our being? Authenticity is the pursuit of that deeper set of truths that empower humans to embrace more meaningful lives. It is rooted in the spiritual search of the great mystics whose spiritual journey evokes renewed interest for many spiritual seekers today. (More in CHRISTIE, 2013; CLARKE, 2005).

Freedom of the Heart. Despite many efforts to deliver freedom from starvation, oppression, warfare and violence, millions are still trapped in the cultural slaveries of our time. In addition, millions more are ensnared in addictions and compulsions arising from dysfunctional social, political and economic systems. While all main religions proclaim a gospel of freedom, many of those same religious systems co-opt oppressive qualities, collude with false domination, and support cultural dysfunctionality. We lack a more authentic spiritual core to bring to fruition our deeper human aspirations, whereby we can co-create a culture conducive to a liberty that transcends all forms of slavery and liberates people for deeper joy and hope in leading a more meaningful life.

Unification of Paradoxes. Dualisitc splitting is one of the inherited curses of our world, a feature unashamedly supported by many major religions. Some popular versions include body v. soul, matter v. spirit, science v. religion, creation v. destruction. All dualisms arise from the compulsive nature of the patriarchal mind-set, purporting binary distinctions as the most effective way to manage daily reality. Increasingly, however, humanity seeks to reclaim a more fundamental 
orientation whereby humans are programmed for cooperation and not for divisive competition (cf. RIFKIN, 2010; WAAL, 2009). Moreover, the deeper truth we yearn for can only be realized by bridging the dualisms and not continuing to perpetuate their increasingly violent outcomes. As suggested earlier in this essay, let us learn to celebrate commonalities, rather than consistently endorsing differences.

Inclusion. Our dualistic cultures, and their religious institutions, tend to favor a culture of exclusion rather than the inclusivity that is central to the Christian Gospel. Others identify us in terms of what we are not allowed to embrace, and we ourselves often collude with such restrictions. All over the world, we hail the empowerment of democratic governance and highlight the regular opportunity to vote in national elections. Between such elections, however, people have little or no say in what transpires, and are helpless to confront their democratically elected leaders when they fail to fulfill, or blatantly flaunt, election promises. Such participative inclusivity is even more limited in religious institutions.

Global Solidarity. The painful division between rich and poor in our world, the corruption underpinning so many political and financial institutions, creates a human disparity that leads to alienation, disempowerment, and extensive human suffering. Even the United Nations, poised to be the catalyst for a more effective sense of global solidarity, is often stymied and emasculated because of nationalistic monopolies enjoyed by the world's superpowers. Moreover, the dualistic split between religion and politics means that world religions, and national churches, have little or no influence on those large-scale forces that undermine the muchneeded universal sense of solidarity. Which brings me to the next and final point from Saade's overview.

Love as the Pursuit of Justice. In the face of national catastrophes - caused by severe weather or social dislocation arising from warfare - people in rich countries give generously, and regional governments often provide rapid 
emergency supplies. All of which is a gesture of love rather than justice. Many of the afflictions experienced in our world, particularly among the poor and marginalized, result from long-term unjust systems - many of which are systemic, economic or political in nature. We lack strategies for global justice, and religions fare poorly in advancing such a vision, mainly because mainline religions favor charity (often felt to be patronizing) rather than empowering justice. The pursuit for justice, and the strategies to bring it about, may well be the single greatest challenge facing an empowering spirituality for the $21^{\text {st }}$ century.

\section{Horizons for the 21st. Century}

These six features characterize the dream and vision of the emerging spirituality. They are deeply integrated with the social and personal aspirations that awaken hope for millions yearning for a world of greater harmony, peace, and happiness. Behind these aspirations are an even deeper set of desires, which I describe as horizons of hope for our age. These are more generalized aspirations but integral to the characteristics outlined by Chris Saade (2014) and developed briefly above. They will require our skilled discernment as we move deeper into the $21^{\text {st. }}$ century.

\section{a) Relationality}

Whereas mainline religion strongly emphasizes autonomy, separation, superiority of magisterial truth, and difference from all that does not belong to a particular faith-system, spirituality seeks out connections, commonalities, and relationships capable of empowering person and planet alike. Frequently, this elicits the accusation of syncretism, which essentially means merging together beliefs and convictions, which should be kept separate. Why? Because, that is 
fundamentally what is required by the standards of classical Greek philosophy which has had an inordinate influence on all aspects of Christian belief.

According to Aristotle, humans need to be rescued from their enmeshment in nature - which today we tend to describe as a convivial relationship with the natural world (see ABRAM, 1996, 2011; CHRISTIE, 2013). But for Aristotle, that close affiliation could undermine the human capacity for rational thought and perception. The proposed remedy was to set the human (particularly the male) as superior to everything in the natural world, with the anthropocentric right to control and govern. Lisa Isherwood, a British theologian, describes this Greek influence as the tyranny of metaphysics (ISHERWOOD, 1999). It ensues in rigid linear divisions of a type quite alien to the modern consciousness, which desires greater harmony, interconnection, and affiliation with all other life forms, a more integrated cosmic and planetary interdependence believed to have been the experience of humans for many thousands of years prior the emergence of Greek philosophy.

Paradoxically, rational science is often invoked to support this new sense of rationality. Quantum physics is particularly cogent in reinforcing this emphasis on the relational web that sustains everything in creation on the micro and macro levels alike. Behind all, the overt physicality and materiality is a whirling generic dance, an elegant, mobile complexity, sustaining every aspect of the created universe. The implications for our emerging spirituality are brilliantly elucidated by the medical-mission Sister, Miriam Therese Winter (2009), providing for the average reader a concise and creative overview of quantum physics.

\section{b) Cosmology/Worldview}

To one degree or another all, the major religions depict the human relationship with creation as a flawed, problematic condition. And the prescribed remedy is also widely consistent: grin and bear it, till you can eventually escape to 
the happiness beyond, the final nirvana. This is radically different from the emerging evolutionary consciousness of our times, which sees human meaning, growth and development as integrally linked to the earthiness of the planet and the energy-empowerment of the entire universe (more in PHIPPS, 2012). Hence, the appeal for many spiritual seekers today of the new physics, the new cosmology, and creation spirituality.

It is grossly irresponsible to dismiss this development as a "new age" fad. It is a subconscious yearning for an earthly conviviality that humans have known for most of their time on earth, one that is vividly re-visioned by the naturalist, David Abram (1996; 2010). It is also a yearning for an ecological integrationessential to a reversal of the extensive destruction humans have caused to the natural world, and essential if we are to evolve a culture based on justice, non-violence, ethical care, and adult responsibility for the womb of our becoming.

The late priest-geologist, Thomas Berry, is the oft-cited authority on the new cosmology (sometimes described as the new story). In conjunction with the physicist, Brian Swimme, Berry has co-authored The Universe Story (BERRY; SWIMME, 1992), a seminal text leading to many other monographs reviewing creation's evolutionary story in a rigorous scientific manner while also embracing an underlying spiritual orientation (eg., PRIMACK; ABRAMS, 2006; DOWD, 2009). Liberation theologian, Leonardo Boff, offers important groundwork integrating liberation theology with the new cosmic story, reinforcing the ecological dimension of contemporary spirituality (BOFF, 1995; 1997; HATHAWAY; BOFF, 2009).

\section{c) Ecology and Mysticism}

A further appeal within the expanded cosmic and planetary view is its innate ability to reawaken religious sentiment with a potential for re-connection far more extensive and deeper than that of formal religion. This sense of awe of supreme 
sacredness tends to be articulated through mystical experiences, known to humans across all ages and cultures. In popular Christian literature, mysticism tends to be described as a kind of absorption into God, beyond all sense of earthly connection (see DREYER; BURROWS, 2005). That exclusive understanding yield's pride of place to the contemporary sense of humans being called to befriend God's creation, and find within it's amorphous sense of mystery tangible evidence for the God who not merely inhabits, but co-creates within, the evolutionary dynamic of creation at large.

Douglas Christie comprehensively describes this new ecologically based spiritual immersion in his elaborate exposition of contemplative ecology: "The term contemplative ecology suggests . . . that there is a way of thinking about spiritual practice that has an ecological character, or a way of thinking about ecology that includes reflection on the moral or spiritual dimensions of experience. ... The aim of contemplative living, in its wider application, is to address the fragmentation and alienation that haunts existence at the deepest possible level and, through sustained practice, come to realise a different, more integrated way of being in the world.” (CHRISTIE, 2013, p. 17, p. 36).

We also glean something of that same mystical intimacy from the priestgeologist, Thomas Berry (2006), from the poetic writings of the late John O’Donohoe (1997), from the feminist, Beverley Lanzetta (2005; 2007), and even from secular naturalist, David Abram $(1996 ; 2011)$ when he writes:

Our greatest hope for the future rests not in the triumph of a single set of beliefs, but in the acknowledgement of a felt mystery, that underlies all our doctrines. It rests in the remembering of that corporeal faith that flows underneath all mere beliefs: The human body's implicit faith in the steady sustenance of the air and the renewal of light every dawn, its faith in mountains and rivers and the enduring support of the ground, in the silent germination of seeds and the cyclic return of the salmon. There are no priests needed in such a faith, no intermediaries or experts necessary to effect our contact with the sacred, since - carnally immersed as we are in the thick of this breathing planet - we each have our own intimate access to the big mystery. (ABRAM, 2011, p. 278). 


\section{d) Ritual Creativity}

Spirituality tends to distinguish ritual from liturgy or sacrament, claiming that the former prevailed for thousands of years long before formal religion ever evolved, and today can be accessed through the rites of passage evidenced among first-nation peoples and among tribal groups on a global scale. Such indigenous rituals are focused not merely on key moments and dimensions of human experience but also embrace the seasonal fluctuations that affect upon the fertility of the land and all the other creatures inhabiting creation.

Such rituals are certainly understood as a dimension of holiness, but do not distinguish between sacred and secular. Local elements such as earth, water, fire, herbs may be extensively used. The facilitation of such rituals tends to be based more on intuitive wisdom and natural leadership skill, although increasingly one does witness a preponderance of the male over the female. In addition, the syncretism arising from religious influence, e.g., the Pentecostal movement with native African Rites of Passage can create outcomes that are psychologically damaging and spiritually problematic.

In the Christian Churches, ritual making is embodied mainly in sacramental experience, viewed in several cases to be the preserve of a special person, namely priest, minister or liturgist. Whereas all people are endowed with the capacity for ritual making, and need to exercise this endowment for their spiritual growth and development, sacramental empowerment casts most people in a passive recipient role, with the selected few exercising ritual initiative. Of course, ritual was never intended to be reduced to sacraments (as understood in mainline churches), and people across the world do engage in other ritualized activities. The deficiency I am highlighting is yet another example of spiritual impoverishment, due to an ecclesiastical monopoly over the creative use of ritual. 


\section{e) Discernment through dialogue and networking}

In mainstream religion, discernment of spirits refers to the need to distinguish between the influence of a good or evil spirit upon a person's desires and behaviors. It is an assumed quality of many patriarchal belief-systems and therefore tends not to be cited explicitly either in theological discourse or pastoral care. If the devotee follows what the legitimate religious authority requires, then, there seems to be an assumption that good discernment is guaranteed.

When the term is used, specifically in the Christian faith, it belongs primarily to the care of souls as exercised in spiritual direction or Retreat ministry. Rarely is the word used in a social, ecclesial context. Here we evidence dualistic splitting within Christian faith itself, with the spiritual dimension relegated a more private, personal and secondary role. Advocates of the new spirituality view this as a deviation and abuse of religious authority, to the point where those in authority seem to consider themselves exempt from spiritual accountability, as long as they follow procedures and directives laid down by higher authority.

Above all else, discernment is about attending to the living Spirit, who is understood to function with a creative freedom that cannot be tied down by any set of institutional norms or procedures. This may well be the single most crucial factor upon which the credibility of the new spirituality stands or falls. It is paralleled in the wider contemporary culture by various movements to engage intelligence and imagination in more collaborative ways, as in new methods of social research (http://en.wikipedia.org/wiki/Action_research). It embraces a more amorphous understanding on how wisdom is acquired, appropriated and utilized, with strong emphasis on dialogue and mutual collaboration. Of particular significance, is a new understanding of the role of the Holy Spirit, reviewed in the next section. 


\section{f) The key role of the Holy Spirit}

In conventional Christian theology, God the Father comes first, as creator and sustainer of all that exists. The Father sends the Son, to rectify and redeem a flaw in creation, specifically in humans. In addition, the Holy Spirit is variously explained as a third mysterious force brought into being through the mutual love of Father and Son.

Christian theology presents quite a confusing description of the Holy Spirit's role. According to Gen.1:1, the Spirit is at work at the dawn of creation, infusing pattern and meaning into the chaotically unfolding process. This would suggest that the Spirit is operative in all creative unfolding thereafter. Yet Christianity claims that the Holy Spirit was not fully available to the Church till after the event of Pentecost (about 2,000 years ago) and that the Spirit only fully relates to the individual person after the reception of Baptism. Sounds like the Church is trying to control the work of the Spirit, and not doing so very ingeniously.

It strikes me that the new spirituality is infused (inspired?) by a sublime desire to rehabilitate the Holy Spirit. Contemporary spirituality does not seem to be consciously aware of this prospect, nor can it seek guidance through the conventional theology of the Holy Spirit, itself hidebound by metaphysical and doctrinal strangulation. Firstly, the history of theology seems to have had long held reservations about the diminished role of the Spirit, playing second fiddle to Father and Son; the new spirituality wants to address this imbalance, seeking a much more exalted role for the Spirit. Secondly, the notion of the Great Spirit in indigenous spirituality (all over the world) incorporates understandings that theology has never considered and that seem to be gaining more significance in our time (more in O'MURCHU, 2012). Thirdly, the rapid and extensive rise of the Pentecostal movement throughout modern Christendom seems to be a sign of our time that deserves a far deeper discernment, a movement that has been widely recognized but not investigated with either spiritual or theological depth (see MARTIN, 2001). 
Are these three factors inter-related? Who in the modern world is exploring their relevance, meaning or integration? In addition, what might be their potential to illuminate the spiritual awakening of our time? These might well be among the most serious questions confronting humanity today, particularly the millions hungering for spiritual meaning, and expressing that hunger in ways that feel everscarier for mainline religions. In this essay, space does not allow for furtherelaboration. I hope to undertake that challenge in a full-length book at another time.

Meanwhile, the Spirit broods where the Spirit wills. Fundamentalist religion is certainly on the ascendency and is often the subject of formal research. Spirituality is viewed more negatively, and often dismissed as a new-age phenomenon or a post-modern social trend. The latter deserves a far more nuanced view and a much more thorough investigation, not merely with the tools of standard research but by researchers with a more discerning eye and an open heart for the surprise, creativity, and unpredictability that characterize the operations of Holy Wisdom in every generation.

\section{REFERENCES}

ABRAM, David. The Spell of the Sensuous. New York: Random House, 1996.

ABRAM, David. Becoming Animal. New York: Vintage Books, 2011.

BERRY, Thomas. Evening Thoughts: Reflecting on Earth as Sacred Community. San Francisco: Sierra Club Books, 2006.

BOFF, Leonardo. Ecology and Liberation. Maryknoll, NY: Orbis Books, 1995.

BOFF, Leonardo. Cry of the Earth, Cry of the Poor. Maryknoll, NY: Orbis Books, 1997. CARRETTE, Jeremy; KING, Richard. Selling Spirituality. London: Routledge, 2005.

CHRISTIE, Douglas E.. The Blue Sapphire of the Mind. New York: OUP, 2013.

CLARKE, Chris. (Ed.). Ways of Knowing: Science and Mysticism Today. Exeter (UK): Imprint Academic, 2005. 
COX, Harvey. The Secular City. London: SCM Press de Waal, 1965.

COX, Harvey . The Age of Empathy. New York: Random House, 2010.

DREYER, Elizabeth; BURROWS. Mark S. Minding the Spirit: The Study of Christian Spirituality. Baltimore, MD: John Hopkins University Press, 2005.

DOWD, Michael. Thank God for Evolution. San Francisco: Council Oak Books, 2009.

ELLWOOD, Robert S. The 6os Spiritual Awakening. New Brunswick, NJ: Rutgers University Press, 1994.

FOX, Matthew. Original Blessing. Santa Fe, NM: Bear \& Co, 1983.

HATHAWAY, Mark; BOFF, Leonardo. The Tao of Liberation. Maryknoll, NY: Orbis Books, 2009.

HEELAS, Paul. Spiritualities of Life: New Age Romanticism and Consumptive Capitalism. Hoboken, NJ: Wiley-Blackwell, 2008.

HEELAS, Paul; WOODHEAD, Linda. The Spiritual Revolution: Why Religion is Giving way to Spirituality. Chichester, West Sussex: John Wiley, 2005.

ISHERWOOD, Lisa. Liberating Christ. Cleveland, OH: Pilgrim Press, 1999.

LANZETTA, Beverly. Radical Wisdom: A Feminist Mystical Theology. Minn: Augsburg/Fortress, 2005.

LANZETTA, Beverly. Emerging Heart: Global Spirituality and the Sacred. Minn: Augsburg/Fortress., 2007.

MARTIN, David. Pentecostalism: The World Their Parish. Hoboken, NJ: WileyBlackwell, 2001.

O’DONOHUE, John. Anam Chara. New York: Bantam Press, 1997.

O’MURCHU, Diarmuid. In the Beginning was the Spirit. Maryknoll, NY: Orbis Books, 2012.

PHIPPS, Carter. Evolutionaries. New York: Harper, 2012.

PRIMACK, Joel; ABRAMS, Nancy. The View from the Center of the Universe. New York: Riverhead Books, 2006.

RIFKIN, Jeremy. The Empathic Civilization. Cambridge, UK: Polity Press, 2009. 
ROOF, Wade Clark. A Generation of Seekers: The Spiritual Journeys of the Baby Boom Generation. San Francisco: Harper SanFrancisco, 1993.

ROOF, Wade Clark. Spiritual Marketplace: Baby Boomers and the Remaking of American Religion. Princeton, NJ: Princeton University Press, 1999.

SAADE, Chris. Second Wave Spirituality. Berkeley, CA: North Atlantic Books, 2014.

SHELDRAKE, Philip. Spirituality and History. London: SPCK, 1991.

SHELDRAKE, Philip. Spirituality: A Very Short Introduction. Oxford (UK): Oxford University Press, 2012.

SWIMME, Brian; BERRY, Thomas. The Universe Story. San Francisco: Harper, 1992.

WINTER, Miriam Therese. Paradoxology: Spirituality in a Quantum Universe.

Maryknoll, NY: Orbis Books, 2009. 